\title{
Technological mineralogy: from Academician V. M. Severgin to the present day
}

\author{
V. V. Shchiptsov 1,2 \\ 1 Institute of Geology, Karelia Science Center RAS, \\ 2 Petrozavodsk State University, Petrozavodsk, Russia \\ vv.shchiptsov@gmail.com
}

It is shown that the origins of technological mineralogy in Russia are associated with the name of Academician V. M. Severgin, who at the end of the 18th century introduced the concept of «technological and economic» mineralogy. The stage of development of 1921-1955 is considered as important for the formation of the school of applied mineralogy. The next stage is the implementation of the principles of technological mineralogy in the practice of geological exploration and mining production and the creation of the Technological Mineralogy Commission of the All-Union Mineralogical Society by the beginning of 1983. The main directions of the development of technological mineralogy and the role of the published works of the commission are substantiated.

Keywords: technological mineralogy, methods, innovative technologies, metals, industrial minerals, georesources.

\section{Технологическая минералогия: от академика В. М. Севергина до наших дней}

\author{
В. В. Щипцов 1,2 \\ 1 Институт геологии ФГБУН Карельский научный центр РАН, \\ 2 Петрозаводский госуниверситет, Петрозаводск, Россия
}

Показано, что истоки технологической минералогии связаны в России с именем академика В. М. Севергина, который в конце XVIII века ввел понятие «технологическая и экономическая» минералогия. Рассмотрен этап развития 1921-1955 гг. как важный для формирования школы прикладной минералогии. На следующем этапе происходит реализация принципов технологической минералогии в практике геологоразведочных работ и горнорудного производства и создание Комиссии по технологической минералогии Всесоюзного минералогического общества (BMO) ${ }^{1}$ к началу 1983 г. Обоснованы главнейшие направления развития технологической минералогии и роль издаваемых трудов комиссии.

Ключевые слова: технологическая минералогия, методы, инновационные технологии, металлы, промышленные минералы, георесурсы.

\section{Introduction}

Currently technological mineralogy is an independent discipline which is a bridge between the geology of ore deposits and methods of processing mineral raw materials to obtain a final product. This branch studies the relationship between composition, structure, physical properties and genetic characteristics of a mineral substance with its technological parameters, which determines the technological assessment of mineral raw materials. It is especially important to study the formation and change of parameters of technological heterogeneity of mineral substance. In this respect, the «mineral - environment» system is interpreted by us as a three-level system - from macro to micro-nanoscale. The development of modern methods of analysis allows fixing the fine and ultrafine heterogeneity of individuals and microaggregates. Such a

${ }_{1}^{1}$ At present - Russian Mineralogical Society / В настоящее время - Российское минералогическое общество (РМО). systematic approach reflects the relationship between the stages of the processes of mineral formation of ores in nature (mineralogenesis) and their transformation during technological processing (technogenesis) from a new point of view. This generally determines indicators of the liberation of intergrowths of minerals during crushing and grinding, the evolution of variability of technological properties of industrial minerals and ores and the efficiency of their separation during processing.

All these data affect features of disintegration and preparation of mineral raw materials for enrichment, the choice of optimal options for liberation of minerals during crushing and grinding, the role of a directed change in the physical properties of mineral components, i. e. substantiates the scientific basis for managing the quality of raw materials, the choice of materials, reagents.

\section{Origins of technological mineralogy}

Academician V. M. Severgin formulated tasks of mineralogy in general, related to the study of the structure

For citation: Shchiptsov V. V. Technological mineralogy: from Academician V. M. Severgin to the present day. Vestnik of Geosciences, 2021, 4(316), pp. 20-24, doi: 10.19110/geov.2021.4.3.

Для цитирования: Щипцов В. В. Технологическая минералогия: от академика В. М. Севергина до наших дней // Вестник геонаук. 2021. 4(316). C. 20-24. DOI: 10.19110/geov.2021.4.3. 
and composition of minerals; clarification of their relationship in the fields; establishing the possibility of their practical use [10]. More than 220 years ago, he at the first time introduced the concept of "technological and economic" mineralogy, which determined the further traditional practical orientation of Russian mineralogy. For 24 years, Severgin published the «Technological Journal», which systematically reviewed results of experimental research and theoretical developments in the technological mineralogy of various objects.

Considering pages of the history of the first half of the $20^{\text {th }}$ century we focus on that in this process a significant role belongs to the development of the foundations of the geological and mineralogical assessment of ores of mineral deposits (1921-1955). Here it is necessary to emphasize that Professor N. M. Fedorovsky generated these ideas related to genetic and economic mineralogy, of which he was the founder [7]. Thus, in fact, the mineralogical school of the Institute of Applied Mineralogy (now VIMS) ${ }^{2}$ was created. The creation of applied mineralogy was welcomed by V. I. Vernadsky [2]. In 1927 he wrote that the past decade simultaneously brought forward a cycle of large and most interesting problems of a sharply different logical category in mineralogy.

During this period and the next stage, mineralogical "cells" (laboratories, departments of material composition for the study of various types of minerals and mineral raw materials in general) are created at the institutes of the geological and technological profile. Researches were carried out on the applied mineralogy of many minerals, the first technological schemes were developed, taking into account the relationship of geological and mineralogical factors with washability and obtaining specific enrichment indicators.

The principles of technological mineralogy began to be widely introduced in practice of geological exploration and mining, which began to be used to assess various genetic types of minerals. This found a specific solution in the work of the largest mining and processing enterprises in the country.

Professor A. I. Ginzburg, based on the generalization of the data of VIMS, scientists and practitioners of other organizations for the study and assessment of mineralogy and, in general, the peculiarities of the material composition of minerals of many deposits in connection with their washability, significantly expanded the range of mineralogical and technological research. He made a huge contribution to the development of prospecting mineralogy based on the study of the typomorphism of minerals, formulated tasks of technological mineralogy and the state of genetic mineralogy [3; 4]. He paid a great attention to the application of modern methods of studying minerals to obtain various geological information that helped to solve practical problems in prospecting and exploration of deposits. A. I. Ginzburg repeatedly said that there were no minerals without practical value, that we simply did not know how to use all of them.

Later, Academician N. P. Yushkin proclaimed the invasion of a new direction in technological mineralogy, linking it with a new scientific paradigm of mineralogy -

2 Fedorovsky All-Union Institute of Mineral Raw / Всероссийский научно-исследовательский институт минерального сырья им. Н. М. Федоровского. the study and assessment of mineral substance, in addition to the macro-, microlevel, and at the nanoscale, taking into account the structural organization of discreteness, evolution (ontogenesis, syngenesis and phylogenesis) in interaction with living matter [14]. In his opinion, nanotechnological solutions are in the basis of future science and practice.

Already today, Professor B. I. Pirogov proclaims that the question of how not to crush, enrich and not extract anything superfluous and to produce high-quality enrichment products, taking into account the principles of the development of technological mineralogy, is very important.

Over the past decades, technological mineralogy became an independent discipline.

In 1982, the $6^{\text {th }}$ Congress of the All-Union Mineralogical Society (AUMS) was held in Leningrad under the auspices of the USSR Academy of Sciences, AUMS, the Ministry of Nonferrous Metallurgy of the USSR, the Mechanobr Institute (Leningrad) and the Leningrad Regional Administration of the Scientific and Technical Society of Nonferrous Metallurgy. In his opening speech as the President of AUMS, Academician A.V. Sidorenko, reviewed a wide range of problems, in which he drew a special attention to the fact that new knowledge about minerals, fine features of their constitution, textural and structural features of ores could serve as a scientific basis for improving existing and creation of new methods of processing, hydrometallurgy and other technological methods.

In order to unite the efforts of scientists and industrial workers on the problems of technological mineralogy, the congress decided to create a commission on technological mineralogy. It was headed by the Director of Mekhanobr V. I. Revnivtsev, who guided it in 1983-1989. From 1989 to 2003, the chairman was V. M. Izoitko. Since 2005, the commission is headed by V. V. Shchiptsov 3

3 The summary article was written by the author for his 80th birthday (April 22, 2021). V. V. Shchiptsov is a well-known researcher in the field of geology of non-metallic mineral resources and their technological assessment, Professor of the Department of Earth Sciences and Geotechnologies of the Institute of Forest, Mining and Construction Sciences of PetrSU. Since 2005 he has headed the Commission for Technological Mineralogy of the Russian Mineralogical Society (RMS), and is the initiator of annual Russian seminars on technological mineralogy. He participates in international projects Fennoscandian Gold Transect (FENGOT) and Fennoscandian Ore Deposit Database and Metallogenic Map (FODD)

Обобщающая статья написана автором к своему 80-летнему юбилею (22 апреля 2021 г.). В. В. Щипцов - известный ученый в области геологии неметаллических полезных ископаемых и их технологической оценки, профессор кафедры наук о Земле и геотехнологий Института лесных, горных и строительных наук ПетрГУ. С 2005 года возглавляет Комиссию по технологической минералогии Российского минералогического общества (РМO), является инициатором ежегодных Российских семинаров по технологической минералогии. Участвует в международных проектах «Fennoscandian Gold Transect» (FENGOT) и «Fennoscandian Ore Deposit Database and Metallogenic Map» (FODD). 


\section{Commission for Technological Mineralogy of the Russian Mineralogical Society}

Since 2006, the RMS Commission has been organizing and conducting Russian seminars on technological mineralogy [8]. The first Russian seminar was held in Petrozavodsk on the basis of the Institute of Geology of the Karelian Science Center of the Russian Academy of Sciences, and was devoted to the consideration of topical issues caused by the peculiarities of geological exploration in Russia.

We can say that modern technological mineralogy combines geological, mineralogical and technological researches.

The experience of the Commission for Technological Mineralogy of the RMS allows us to speak about some results of the research of the established school [8]. In space and time, the structure of consumed mineral resources and consumption volumes change.

The solutions of scientific problems are based on new methods of technological mineralogy at evaluating metal ores and industrial minerals, improving methods of technological mineralogy at the early stages of geological exploration and operational exploration, morphological and constitutional features of small particles and their role in technological processing of mineral raw materials, directed changes in the technological properties of mineral raw materials and the production of new materials, the role of technological mineralogy in solving the problems of the integrated use of mineral raw materials in the extraction and processing, the study of the features of the mineralogical and technological assessment of natural and technogenic mineral raw materials, the determination of a rational complex of mineralogical and technological methods for the study of mineral raw materials, the development of a system of geological and technological modeling when mapping mineral deposits of various genetic types.

\section{Results of the work of the Commission for technological mineralogy and their discussion}

The issues that were considered by the Commission at seminars held in various parts of Russia and other events were published in a large series of works on technological mineralogy.

In Moscow, in May 2018, a Russian meeting on the topic «The Role of Technological Mineralogy in Rational Subsoil Use» was successfully held at VIMS. The next year, for the first time on the territory of the Russian Federation, the International Congress ICAM-2019 was held on the basis of the Belgorod State Technological University named after V. G. Shukhov from 23 to 27 September 2019 [1].

In December 2020, the next seminar on technological mineralogy was held in Syktyvkar, where the Bureau of the Commission presented a plenary report «Technological mineralogy in the entire space» [9].

In this section, the author refers to selected brief research results related to the problems of technological mineralogy.

Minerals (aggregate aggregates) are regular natural chemical polycompounds. Multicomponent systems of minerals are investigated by analytical methods and new generation instruments. The use of high-level equipment allows identifying reasons for the low level of technology of raw materials and propose new approaches to improve the estimates.

The role of technological mineralogy comes to the fore in the development of a strategy for the use of minerals, which is governed by three megatrends. The first megatrend is the global struggle for resources. This is connected to the limited access to mineral reserves to use the mineral wealth. The second trend corresponds to the technologies of the 21 st century, in which a significant place is given to metals and industrial minerals. Their application develops high geotechnologies. New research opportunities are discovered. The third trend focuses on efficient materials and energy, new mineral resources and high-tech mining.

New development technologies aim at involving refractory and refractory raw materials, developing a new class of materials based on mineral raw materials and improving the quality of raw materials to the level of pure and super pure concentrates. It becomes vitally important to intensify enrichment technologies for various ores of metals and industrial minerals based on a directed change in the properties of minerals (cryotherapy, activation, leaching, exposure to ultrasound, chemically active plasma, microwave radiation, proton irradiation, exposure to powerful electromagnetic pulses, ion implantation, etc. (Fig. ) [6]

Here is one example: the recorded deposits and occurrences of quartz raw in the Karelia-Kola region were estimated at a modern level, and an innovative technology for purifying quartz was developed [11]. Both traditional and non-traditional types of quartz raw were evaluated using the latest techniques in the field of geological and technological study of quartz. The method of a technological and effective method for assessing the quality of quartz raw materials allows at the preliminary stage of assessment to objectively predict the quality of quartz raw and the direction of its use. The technical result of the proposed method is to improve accuracy, as well as simplify the process of assessing the quality of quartz raw. A patent for a method for purifying quartz is more productive because of intensification of the process of purifying quartz from impurities, reduces energy consumption, simplifies enrichment technologies, ensures high environmental friendliness, which allows it to be classified as high-tech, environmentally friendly and energy-saving technologies. All these can result in expansion of the mineral resource base of quartz raw and increase in the utilization rate of subsoil resources $[11,15,16]$. The project of the Institute of Geology of the Karelian Science Center of the Russian Academy of Sciences «Superpure quartz: Karelia-Kola quartz-bearing province of Russia» was awarded a special prize of the St. Petersburg International Technical Fair in March 2017 and the exhibition «High Technologies. Innovation. Investment» (Hi-Tech).

In the practical use of shungite rocks, a number of problems arise, which are associated with the heterogeneity of raw even within one deposit, both in chemical composition and in the structural parameters of carbon and rocks in general. If, in terms of chemical composition, certification requirements for raw materials were developed and were available, then in terms of structural parameters, such requirements were not considered, namely, the structure of carbon determined main properties of shungite rocks. This situation results in the fact that one batch of shungite raw materials demonstrates excellent properties, for example, when used in metallurgical processes, the 


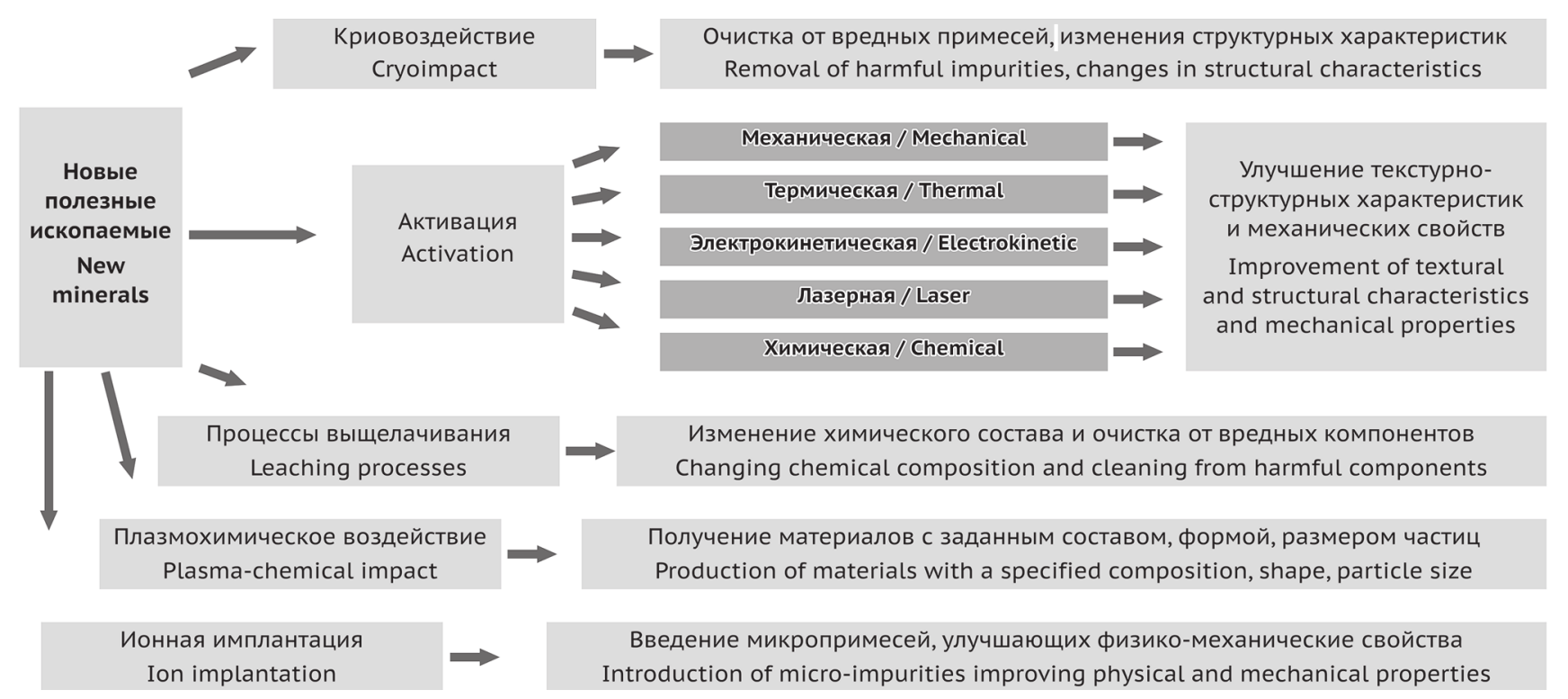

Directed change of the technological properties of mineral raw and production of new materials [6]

Направленное изменение технологических свойств минерального сырья и получение новых материалов [6]

other is satisfactory, and the third generally leads to defective products.

Geological prospecting works on industrial types of shungite rocks allowed classifying geological and industrial types of shungite rocks, determining the most promising areas of occurrence of shungite rocks. In fact, the implementation of the planned work will lead to an effective investment of the funds in the cost of future deposits and the development of innovative approaches to the use of Russian unique carbon-containing raw materials $[5,13,14]$.

\section{Conclusions}

The tasks of technological mineralogy in the 21th century are determined by the objective need to improve technological processes, develop and scientifically substantiate new technological approaches and technical solutions in connection with the involvement of completely new metals and chemical elements, mineral raw materials of technogenic origin in the industrial sphere. Attention to the integrated use of mineral raw materials is significantly increasing.

Modern strategies for the development of individual fields should provide for the possibility of preventing and compensating for the negative impacts of the external environment, as well as quickly reacting to favorable economic situations.

The basic principle provides for the development of deposits in the form in which nature created it. Georesources must be brought to the most suitable condition for extraction using modern technologies.

A new principle that fosters innovation is laid in the basis of the semantic concept of «accessibility». The accessibility of mineral resources is a property of the «society - mineral resources» system, which characterizes the possibility of their efficient and safe application depending on the state of the resources, the need for them and the achieved technological level.

The work was supported by the $R \& D$ project $210 I G$ KarSC RAS 121040600173-1.

\section{References}

1. Askhabov A. M., Kotova O. B. Horizons of applied mineralogy. RMS Proceedings (Proc. Russian miner. Soc.), 2019, No 6, pp. 117-126. https://doi.org/10.30695/zrmo/2019.1486.06 [in Russian].

2. Vernadsky V. I. Selected works. Moscow: AS USSR, 1954, book 1, 700 p. [in Russian].

3. Ginzburg A. I. On minerals-geochemical indicators and their significance in the search for rare metal ores in pegmatites. Doklady Earth Sciences USSR, V. 98, No. 2, 1954 [in Russian].

4. Ginzburg A. I., Kuzmin V. I., Sidorenko G. A. Mineralogical studies in the practice of geological exploration. Moscow: Nedra, 1981, 237 p. [in Russian].

5. Kalinin Yu., Kovalevsky V. Shungite rocks: horizons of scientific searc. Nauka v Rossiya, 2013, No. 6, pp. 66-72 [in Russian].

6. Lygina T. Z. Complex processing of nonmetallic minerals - as the basis of innovative projects. The significance of technological mineralogy research in solving problems of complex development of mineral raw materials. Petrozavodsk: KarSC RAS, 2007, pp. 28-34 [in Russian].

7. Paramonov I. V., Korobochkin N. P. Nikolai Mikhailovich Fedorovsky (1886-1956). Moscow: Nauka, 1979, 166 p. [in Russian].

8. Pirogov B. I. V. V. Shchiptsov History of the Commission for Technological Mineralogy of the RMS (AUMS) with a prologue. RMS Proceedings, 2016, part 1, issue 7, pp. 84-103 [in Russian].

9. Ponaryadov A. V., Shushkov D. A. Traditional meeting of mineralogists (Yushkin readings - 2020). Vestnik of Geosciences, 2020, No. 12, pp. 40-42 [in Russian].

10. Severgin V.M. The first foundations of mineralogy, or the natural history of deposit. Book 1, St. Petersburg: IAN, 1798, 82 p. [in Russian].

11. Shchiptsov V. V., Bubnova T. P., Svetova E. N., Skamnitskaya L. S. Quartz raw materials of the Karelia-Kola region: main research results. Tr.KarSC RAS (series «Geology of the Precambrian»). 2020, issue 10, pp. 5-25 [in Russian].

12. Yushkin N. P. Modern mineralogy and new trends in its development. New ideas and concepts in mineralogy. Syktyvkar: 2002, pp. 8-9 [in Russian]. 
13. Kovalevsky V. \& Shchiptsov V. Shungites and their Industrial Potential. 14 ${ }^{\text {th }}$ International Congress for Applied Mineralogy (ICAM2019). Springer Proceedings in Earth and Environmental, 2019, pp. 201-204.

14. Kovalevsky V., Shchiptsov V., Sadovnichy $R$. Unique natural carbon deposits of shungite rocks of Zazhogino ore field, Republic of Karelia, Russia. International Multidisciplinary Scientific GeoConference Surveying Geology and Mining Ecology Management, SGEM Conference Proceeding, 2016, pp. 673-680.
15. Shchiptsov V. V., Scamnitskaya L. S, Bubnova T. P. Geological and economic evaluation of quartz from the Republic of Karelia, Russia. 14-th GeoConference on science and technologies in geology, exploration and mining. Conference proceedings. Sofia Bulgaria. 2014, V. 1, pp. 153-160.

16. Shchiptsov V. V., Skamnitskaya L. S., Rakov L. T., Dubinchuk V. T. Genetic value and the technological importance of structural not uniformity of submicroscopic level in quartz. SGEM2015 Conference Proceedings. Sofia Bulgaria 2015, Book 1, V.1, Section Geology, pp. 395-402.

Received / Поступила в редакцию 15.04.2021 